\title{
Polysomnographic, demographic and clinic differences between male and female obstructive sleep apnea patients
}

\author{
Merda ERDEMIR IŞIK ${ }^{\mathbf{1}}$ (ID) \\ Banu GÜLBAY ${ }^{2}(\| \mathrm{D})$ \\ Fatma ÇiFTCi ${ }^{2}$ (ID) \\ Turan ACICAN ${ }^{2}$ (ID)
}

\footnotetext{
${ }^{1}$ Clinic of Chest Diseases, Medicana International İzmir Hospital, İzmir, Turkey

${ }^{1}$ Medicana International İzmir Hastanesi, Göğüs Hastalıkları Kliniği, İzmir, Türkiye

${ }^{2}$ Department of Chest Diseases, Ankara University Faculty of Medicine, Ankara, Turkey

${ }^{2}$ Ankara Üniversitesi Tıp Fakültesi, Gögüs Hastalıkları Anabilim Dalı, Ankara, Türkiye
}

Cite this article as: Erdemir lşık $M$, Gülbay B, Çiftci F, Acican T. Polysomnographic, demographic and clinic differences between male and female obstructive sleep apnea patients. Tuberk Toraks 2020;68(4):361-370.

\section{Yazışma Adresi (Address for Correspondence)}

\section{Dr. Merda ERDEMIR ISIIK}

Medicana International İzmir Hastanesi, Göğüs Hastalıkları Kliniği, IZMIR - TÜRKIYE

e-mail: drmerdaerdemir@yahoo.com

\footnotetext{
CCopyright 2020 by Tuberculosis and Thorax.
}

Available on-line at www.tuberktoraks.org.com

\begin{abstract}
Polysomnographic, demographic and clinic differences between male and female obstructive sleep apnea patients

Introduction: The differences between both genders with Obstructive Sleep Apnea Syndrome (OSAS) which is often seen in males can be explained by means of certain polysomnographical parameters and demographical and clinical features. The aim of this research study is to research the gender differences in Turkish population in terms of polysomnographical parameters and demographical and clinical features, and to compare and contrast the results of this research with the results of literature.
\end{abstract}

Materials and Methods: This study has been carried out by including 100 females and 116 males, 216 patients in total, who were diagnosed with OSAS in the Sleep Laboratory of the Medicine Faculty, Ankara University between the years of 2011 and 2014. The demographical information like the ages and the genders of all patients and the figures of the height, weight and body-mass index (BMI) have been recorded. The Epworth Sleepiness Scale (ESS) of patients have also been recorded. Acquired by the polysomnography equipment, the polysomnographical data of all patients having the criteria of this study have been evaluated.

Results: The average age of female patients, which is $57.2 \pm 9.1$ (the lowestthe highest), has been found to be meaningfully high $(p<0.05)$ when compared to the average age of male patients $(50.9 \pm 11.8)$. The body-mass index (BMI) averages of female patients, which are $35.4 \pm 9.2$, have been determined to be high $(p<0.05)$ when compared to the body-mass index (BMI) average of male patients $(32.5 \pm 6.7)$. The total Apnea Hypopnea Index (AHI) of male patients have been found to be meaningfully higher than of the fema- 
le patients $(p<0.05)$. Mild and moderate OSAS in female patients have been observed at a higher rate than males. On the other hand, severe OSAS has been observed at a higher rate than females $(p<0.05)$. Likewise, while the average obstructive apnea time in male patients has been for $17 \pm 5.8$ seconds, the same figure has been for $14.5 \pm 4.4$ seconds $(p<0.05)$.

Conclusion: As a result, in this study, we have observed that females suffering from OSAS are older and obese at a more rate and they have lower Apnea Hypopnea Index (AHI) than the males with OSAS. We have also distinguished that the symptoms related to OSAS of both genders are similar despite the lower Apnea Hypopnea Index of females. Meanwhile we want to emphasize that clinicians need to take these factors into consideration while focusing on the diagnosis of OSAS in female patients.

Key words: Obstructive sleep apnea; polysomnography; gender differences

\section{ÖZ}

\section{Obstrüktif uyku apneli kadın ve erkek hastalar arasında polisomnografik, demografik ve klinik açıdan farklılıklar}

Giriş: Obstrüktif uyku apne sendromu (OSAS), üst hava yollarının parsiyel ya da tam tıkanması sonucu, uyku sırasında oksijen desatürasyonları ve uyku bölünmeleri ile sonuçlanan sık solunum durma epizodları ile karakterize bir hastalıktır. Bu çalışmada Türk populasyonunda polisomnografik parametreler, demografik ve klinik özellikler açısından cinsiyet farklııklarının araştırılması ve sonuçlarının literatürdeki sonuçlarla karşılaştırılması amaçlanmıştır.

Materyal ve Metod: Çalışmaya 2011-2014 yılları arasında Ankara Üniversitesi Tıp Fakültesi Uyku Laboratuvarı́nda OSAS tanısı almış 100 kadın 116 erkek olmak üzere toplam 216 hasta dahil edilmiştir. Tüm hastaların yaş ve cinsiyet gibi demografik bilgileri ile boy, kilo ve beden kitle indeksi değerleri, horlama, gün içi aşırı uykululuk, tanıkı apne, sabah uyandığında baş ağrısı, baş-boyun terlemesi ve nefes darlığını içeren semptom kayıtları, PSG öncesi uygulanmış olan ESS sonuçları kaydedildi. Çalışma kriterlerine sahip olan tüm hastaların PSG verileri değerlendirildi.

Bulgular: Kadın hastaların yaş ortalaması $57.2 \pm 9.1$ olup, erkek hastaların yaş ortalamasına (50.9 \pm 11.8 ) göre anlamlı olarak yüksek bulunmuştur $(p<0.05)$. BKi açısından bakıldığında kadın hastaların BKi ortalamaları $35.4 \pm 9.2$ olup erkek hastaların BKi ortalamasına göre $(32.5 \pm 6.7)$ daha yüksek saptanmıştır $(p<0.05)$. Semptomlar ve ek hastalıklar açısından bakıldığında her iki cinsiyet arasında anlamlı fark bulunmamıştır ( $p>$ 0.05). Ortalama obstrüktif apne sayısına bakıldığında, erkek hastaların ortalaması $56 \pm 129$ olarak bulunmuş olup, kadın hastaların ortalamasına göre (32 \pm 84.1) yüksek saptanmışır $(p<0.05)$. Ortalama obstrüktif apne sürelerine bakıldığında da,erkek hastaların ortalaması $17 \pm 5.8$ olarak bulunmuş olup, kadın hastaların ortalamasına göre (14.5 \pm 4.46) yüksek saptanmıştır $(p<0.05)$. OSAS'lı erkek hastalarda Total AHI OSAS'ı kadın hastalardan anlamlı olarak yüksek bulunmuştur ( $p<0.05)$. AHI NREM erkek OSAS'lı kadınlarda, AHI REM ise kadın OSAS'lı hastalarda yüksek bulunmuş fakat her iki parametre için cinsiyetler arası istatistiksel anlamlı fark bulunmamıştır.Kadınlarda hafif ve orta derecedeki OSAS erkeklere göre daha yüksek oranda gözlenirken; ağır OSAS ise erkeklerde kadınlara göre daha yüksek oranda gözlenmiş olup, bu farklııklar istatistiksel olarak anlamlı bulunmuştur $(p<0.05)$

Sonuç: OSAS'ı kadınların OSAS'ı erkeklerden daha yaşı ve obez olduğunu, daha düşük AHI değerine sahip olduklarını, semptomlarının benzer olduğunu gözlemlerken, klinisyenlerin kadın hastalarda OSAS tanısını düşünürken bu faktörleri göz önüne almaları gerektiğini vurgulamak istedik

Anahtar kelimeler: Obstrüktif uyku apnesi; polisomnografi; cinsiyet farklıııları

\section{INTRODUCTION}

Obstructive Sleep Apnea Syndrome (OSAS) is a common disease which affects at least $5 \%$ of the general population and which is resulted in oxygen desaturation and sleep disruption during sleep in consequence of the partial or complete obstruction of upper airway and consequently which is characterized by the frequent episodes of respiratory arrest (1). Due to excessive daytime sleepiness caused by OSAS, disorders in neurohumoral behaviors, hypertension and cardiovascular diseases, increase in car accidents, impairment in the quality of life and functional impairment have been seen (1). Although the ratio of male/female has been found as 2-3/1 in the OSAS studies carried out in the general population, it has been observed that this ratio is higher than $8 / 1$ in clinical population $(2,3)$. In the research studies carried out on the gender differences related to the anatomy and the function of upper airway, the weight and the weight distribution in the body, the control of respiration and hormonal status, it has been shown that being a male is a high risk factor for OSAS (4-10). It has been thought that the rates of diagnosis are low because women with clinically OSAS have applied to the clinic with different complaints, the differences of their tolerance to the symptoms or because of their atypic symptoms. Walker and his friends have determined that the body-mass index (BMI) in women are higher than men and that much elder age and milder OSAS are seen in these women when the demographical factors are taken into consideration (3). 
When the effects of menopause on women with OSAS are considered and when they are compared to premenopausal women, the prevalence of OSAS in postmenopausal women has been found to be higher (11) and it has been observed that the majority of women with OSAS are in their postmenopausal period. According to Ware and his friends, the number of obstructive apnea is less in female patients with OSAS when compared to male patients with OSAS who have similar ages and BMI to these women. However they have also showed that the number of apnea is similar both in males at later ages (60-88 years) and females. As a result, they have indicated this case can be explained by menopausal effect and the muscle strength of upper respiratory tract (12).

The aim of this research study is to research the gender differences in Turkish population in terms of polysomnographical parameters and demographical and clinical features, and to compare the results of this research with the results of literature.

\section{MATERIALS and METHODS}

\section{Selection of patients}

Retrospectively and in a cross-sectional way, this study has been carried out by including 100 females and 116 males, 216 patients in total, who were diagnosed with OSAS in the Sleep Laboratory of the Medicine Faculty, Ankara University between the years of 2011 and 2014.

Patients who haven't been diagnosed with OSAS as a result of the polysomnography (PSG) and the ones who have had split night PSG, and the patients whose sleep efficiency during PSG has been detected below $60 \%$ and the ones whose total sleep duration is under 180 minutes have been excluded from this study.

\section{Protocol}

The demographical information such as the age and the gender, the body-mass index values, and the symptoms record including snoring related to OSAS, excessive sleepiness during a day, witnessed apnea, headache and sweating of head and neck when they wake up in the morning and coexisting diseases together with the results of Epworth Sleepiness Scale (ESS) have been recorded.

Carried out with Comet Plus (Grass Technology, An Astro-Med, Inc. Subsidiary, West Warwick the USA), the PSG data of all patients having the criteria of the study have been evaluated. In the polysomnography record, a thermistor and a nasal pressure have synchronously been used for electroencephalogram (EEG) (C4-A1, C3-A2, O1-A2, O2-A1), electrooculogram (EOG) (E1-E2) and submental-anterior electromyogram (EMG), electrocardiogram (ECG) airflow monitorization. The ventilator effort has been calculated by the method of plethismography inserted around the thorax and abdomen via sensors. Arterial oxygen saturation has consistently been monitored nightlong with pulse oximetry by using a finger probe. The position of body has been monitored by the body position sensor and the video recording. All date has been scored manually after being saved in a computer system.

\section{Polysomnography}

Stages of sleep and respiratory cases have been scored by polysomnography analysis program according to the international criteria of sleep disorders (AASM 2007).

TST (Total Sleep Time) has been calculated as time from the onset of sleep to the end. Sleep onset has been accepted as the period from the time when it is lighted off for PSG recording to the onset of sleep phase. Sleep efficiency has been detected as total sleep time / total bedtime x 100. After the stages of sleep have been manually scored according to the international rules, the percent values obtained by the proportion of each sleep stage time to the total sleep time by the software program of sleep device [N1 (\%), N2 (\%), N3 (\%), REM (\%)]. The number of arousal per total sleep time has been defined as Arousal Index.

Obstructive apnea has been defined as the absence of airflow for more than 10 seconds although respiratory effort is going on. Central apnea has been defined as the absence of airflow for more than 10 seconds due to loss of respiratory effort. Mixed apnea has been defined as ongoing apnea which is of central type at the beginning although respiratory effort starts. Two different kinds of definitions for hypopnea have been used. For the patients until 09/2012, it has been used that "in the recording carried out on the basis of nasal pressure cannula the respiratory amplitude during sleeping decreases by at least $50 \%$ when compared to the onset value, the case of obstructive lasts for at least 10 seconds, decrease about 3\% in saturation when compared to basal saturation before 
the case and/or arousal, at least $90 \%$ part of the case meets the amplitude decreasing criteria accepted in hypopnea." For the patients after 09/2012, it has been used that "respiratory amplitude during sleeping has decreased by at least $30 \%$ for about 10 seconds or more with nasal pressure cannula when compared to the onset value and decrease about $3 \%$ in saturation when compared to basal saturation before the case and/or respiratory case ends with arousal, reduce in amplitude by $30 \%$ lasts $\geq 10$ seconds."

Apnea Hypopnea Index (AHI) defines the total number of apnea and hypopnea per total sleep time. The total number of apnea and hypopnea per NREM sleep time has been defined as NREM AHI and the total number of apnea and hypopnea per REM sleep time has been defined as REM AHI.

The time between the onset and the endpoint of each respiratory case scored during the recording has been identified as the time of the related respiratory case (obstructive apnea time, central apnea time, mixed apnea time, hypopnea time). All mean values have been scored by the software program of the sleep system.

OSAS has been described as the fact that $\mathrm{AHI} \geq 5$ is found in the polysomnography applied to the patient who shows one of the symptoms of excessive daytime sleepiness, disorderly snoring or witnessed apnea. Grading the severity of OSAS has been carried out according to AHI. Patients with AHI 5-15 have been accepted as mild moderate OSAS, the ones with $\mathrm{AHI} 15-30$ as moderate OSAS and the patients with $\mathrm{AHI}$ over 30 as severe OSAS.

\section{Statistics}

The analysis of data has been performed in the package program of "SPSS for Windows 15". Descriptive variables have been shown as mean \pm standard deviation for dispersion-normal variables and for dispersion-abnormal variables they have been shown as median (min-max), and nominal variables have been shown as number of case and \%.
The importance of difference between the groups in terms of means has been analyzed with " $t$ test", the importance of difference in terms of median values has been analyzed with "Mann Whitney $U$ test". Nominal variables have been evaluated with "Pearson Ki-Kare or Fisher exact test". The results have been accepted to be statistically significant for $\mathrm{p}<0.05$.

\section{RESULTS}

This study has been carried out by including 100 females and 116 males between 22-85 years old, 216 patients in total who were diagnosed with OSAS in the Sleep Laboratory of the Department of Chest Diseases, Medicine Faculty, Ankara University between the years of 2011 and 2014.

The average age of female patients is $57.2 \pm 9.1$ (2277) and the average age of male patients is $50.9 \pm$ 11.8 (26-85). The difference between the genders has been found to be significant $(p<0.000)$. The bodymass index (BMI) averages of female patients (35.4 \pm 9.2) have been found to be significantly high ( $p=$ 0.01) when compared to the body-mass index (BMI) average of male patients $(32.5 \pm 6.7)$ (Table 1$)$.

The average of these groups has been found to be 12 in the results of ESS and no significant differences between two groups have been able to be detected. The average of ESS results is similar in both genders with mild and moderate OSAS. On the other hand the average of ESS scores in patients with severe OSAS has increased (Table 1).

Snoring, excessive daytime sleepiness and witnessed apnea have been determined to be the presenting complaints in all patients of both groups. No significant differences in symptoms such as morning headache, head-neck sweating between female and male patients have been found. When additional diseases are considered, no significant differences in hypertension, atherosclerotic heart diseases (ASKH), diabetes mellitus (DM), arrhythmia, gastroesophageal reflux disease (GERD) have been determined. Depression determined to be higher in female

Table 1. Demographical information of patients with OSAS

\begin{tabular}{|c|c|c|c|}
\hline & Female $(n=100)($ Median \pm SD $)$ & Male $(n=116)($ Median \pm SD $)$ & p \\
\hline Age (year) & $57.2 \pm 9.1$ & $50.9 \pm 11.8$ & $<0.000$ \\
\hline $\mathrm{BKI}\left(\mathrm{kg} / \mathrm{m}^{2}\right)$ & $35.4 \pm 9.2$ & $32.5 \pm 6.7$ & 0.01 \\
\hline ESS & $12 \pm 5.1$ & $12 \pm 5.4$ & 0.605 \\
\hline
\end{tabular}


patients with OSAS than in males has been found to be statistically borderline significant (Table 2).

\section{The Polysomnography Findings of Female and Male Patients with OSAS}

No significant differences have been determined between the two groups of patients in terms of mean values of total sleep time, sleep onset and sleep efficiency percentage. Mean Arousal Index value of male patients, which is $21.2 \pm 16.4$, has been determined to be significantly high when compared to the female patients group $(15 \pm 15.3)(p<0.01)($ Table 3$)$.

When sleep architecture of patients are compared, the percentage of $\mathrm{N} 1$ sleep time in male patients, which is $13.4 \pm 11.7$, has been determined to be significantly higher than the female patients' $(10.1 \pm$ 11.1) $(p<0.05)$. On the other hand, the percentage of N3 sleep time in female patients, which is $16.0 \pm$
10.2 , has been found to be significantly higher than the male patients' $(11.1 \pm 10.3)$. Among female and male patients with OSAS, no significant differences between the percentages of N2 and REM stages have been found ( $p>0.05$ ). (Table 3 ).

\section{The Differences of Respiratory Cases in Female and Male Patients with OSAS}

The number and the time of obstructive apnea on average in male patients have been found to be statistically higher $(p<0.05)$. The number and the time of central apnea have been found to be similar in both groups and no statistically significant differences have been determined ( $p>0.05$ ) (Table 4). Similarly no significant differences have been determined between mixed apnea time on average ( $p>0.05$ ) while the number of mixed apnea on average in males has been found be statistically high $(\mathrm{p}<0.05)$ (Table 4$)$. In both groups, the number of obstructive apnea has been

\begin{tabular}{|c|c|c|c|}
\hline & Female $(n=100)$ & Male $(n=116)$ & $\mathbf{p}$ \\
\hline \multicolumn{4}{|l|}{ Symptoms } \\
\hline Snoring & $100(100)$ & 100 & $>0.05$ \\
\hline Excessive daytime sleepiness & 100 & 100 & $>0.05$ \\
\hline Witnessed apnea & 100 & 100 & $>0.05$ \\
\hline Headache & 19 & 25.8 & $>0.05$ \\
\hline Head-neck sweating & 16 & 29.3 & $>0.05$ \\
\hline \multicolumn{4}{|l|}{ Coexisting diseases } \\
\hline Hypertension & 25 & 33 & $>0.05$ \\
\hline ASKH & 4 & 12 & $>0.05$ \\
\hline Diabetes mellitus (DM) & 14 & 12 & $>0.05$ \\
\hline Arrhythmia & 3 & 4 & $>0.05$ \\
\hline GERD & 7 & 10 & $>0.05$ \\
\hline Depression & 8 & 4 & 0.059 \\
\hline
\end{tabular}

Table 3. The polysomnography findings of female and male patients with OSAS

\begin{tabular}{|c|c|c|c|}
\hline & Female $(n=100)($ Median \pm SD) & Male $(n=116)($ Median \pm SD $)$ & $\mathbf{p}$ \\
\hline TST (min) & $283.7 \pm 77.1$ & $279.5 \pm 79.9$ & 0.621 \\
\hline Sleep onset (min) & $10.5 \pm 40$ & $14 \pm 14.3$ & 0.079 \\
\hline Sleep efficiency (\%) & $74.2 \pm 16.2$ & $78 \pm 12.2$ & 0.341 \\
\hline Arousal index & $15 \pm 15.3$ & $21.2 \pm 16.4$ & 0.001 \\
\hline N1 (\%) & $10.1 \pm 11.1$ & $13.4 \pm 11.7$ & 0.008 \\
\hline N2 (\%) & $64 \pm 14.3$ & $62.7 \pm 13.9$ & 0.0706 \\
\hline N3 $(\%)$ & $16 \pm 10.2$ & $11.1 \pm 10.3$ & 0.001 \\
\hline REM (\%) & $8.5 \pm 6.6$ & $9.6 \pm 6.2$ & 0.092 \\
\hline
\end{tabular}


seen more in NREM sleep than REM sleep. The average number of obstructive sleep apnea in NREM sleep in male patients has been found to be $52 \pm 122.9$ and has been determined to be higher than the average number of female patients $(24 \pm 81.4)(p<0.05)$. The number of obstructive sleep apnea in REM sleep has been found to be similar among female and male patients and no significant differences between these two groups have been determined ( $p>0.05)$. It has been shown in Table 4 that there are no significant differences between the groups of female and male patients in terms of the average hypopnea number and time values ( $p>0.05$ ).

The average of total $\mathrm{AHI}$ in males, which is $30.4 \pm 31$, has been found to be higher than the average AHI of female patients $(17.7 \pm 25.2)(p<0.05)$. In terms of the average $\mathrm{AHI}$ values calculated NREM and REM sleep, AHI has been found to be high in females in REM sleep and high in males in NREM sleep. However no significant differences have been determined between the groups ( $p>0.05$ ) (Table 5).

The lowest average value of $\mathrm{SpO}_{2}$ at night in female patients with OSAS $(73 \pm 18)$ has been determined to be significantly lower than male patients $(78 \pm 18)$ $(p<0.05)$ (Table 5). No significant differences have been determined between the groups of patients in terms of the average value of $\mathrm{SpO}_{2}$ at night ( $\left.\mathrm{p}>0.05\right)$ (Table 5).

Mild and moderate OSAS in female patients have been observed at a higher rate than males. On the other hand, severe OSAS has been observed at a higher rate in males than in females. These differences have been found to be statistically significant $(p<$ 0.05) (Table 6).

Table 4. The respiratory cases of female and male patients with OSAS

\begin{tabular}{|lccc|} 
& Female $(\mathbf{n}=\mathbf{1 0 0})$ (Median $\pm \mathbf{S D})$ & Male $(\mathbf{n = 1 1 6})($ Median \pm SD) & $\mathbf{p}$ \\
\hline Average number of central apnea & $0 \pm 0.6$ & $1 \pm 15.5$ & 0.128 \\
Average time of central apnea (second) & $0 \pm 6.4$ & $8 \pm 6.7$ & 0.348 \\
Average number of mixed apnea & $0 \pm 11.3$ & $3 \pm 38.8$ & 0.0 \\
Average time of mixed apnea (second) & $11.5 \pm 8.7$ & $56 \pm 129.0$ & 0.126 \\
Average number of obstructive apnea & $32 \pm 84.12$ & $17 \pm 5.8$ & 0.002 \\
Average time of obstructive apnea (second) & $14.5 \pm 4.46$ & $42 \pm 36.8$ & 0.017 \\
Average number of hypopnea & $32.5 \pm 48$ & $16 \pm 3.9$ & 0.453 \\
Average time of hypopnea (second) & $15 \pm 3.5$ & 0.178 \\
\hline
\end{tabular}

Table 5. Apnea hypopnea index of female and male patients with OSAS

\begin{tabular}{|c|c|c|c|}
\hline & Female $(n=100)($ Median \pm SD $)$ & Male $(n=116)($ Median \pm SD $)$ & $\mathbf{p}$ \\
\hline AHI NREM & $14.7 \pm 149.2$ & $23.5 \pm 40.0$ & 0.215 \\
\hline AHI REM & $20.3 \pm 27.1$ & $16.5 \pm 29.1$ & 0.415 \\
\hline AHI Total & $17.7 \pm 25.2$ & $30.4 \pm 31.0$ & 0.00 \\
\hline The average $\mathrm{SpO}_{2}$ value at night & $90 \pm 6$ & $91 \pm 5$ & 0.8 \\
\hline The lowest $\mathrm{SpO}_{2}$ value at night & $73 \pm 18$ & $78 \pm 18$ & 0.04 \\
\hline
\end{tabular}

Table 6. Rating of OSAS in female and male patients

\begin{tabular}{|lccc|}
\hline AHI & $\begin{array}{c}\text { Female }(\mathbf{n}=\mathbf{1 0 0}) \\
(\mathbf{n} / \mathbf{\%})\end{array}$ & $\begin{array}{c}\text { Male }(\mathbf{n}=\mathbf{1 1 6}) \\
(\mathbf{n} / \mathbf{\%})\end{array}$ & $\mathbf{p}$ \\
\hline 5-15 (mild OSAS) & $42 / 42$ & $32 / 27.5$ & 0.01 \\
15-30 (moderate OSAS) & $34 / 34$ & $26 / 22.4$ & 0.01 \\
$>30$ (severe OSAS) & $26 / 26$ & $59 / 50.8$ & 0.01 \\
\hline
\end{tabular}

366 Tuberk Toraks 2020;68(4):361-370 


\section{DISCUSSION}

In this study, it has been determined that there are significant differences between our female and male patients with OSAS in terms of demographical and polysomnographical data. The average age of female patients with OSAS has been found to be higher than male patients.

It has been reached to the similar data which shows the average of male patients are lower in several literature samples in which patients with OSAS have been analyzed. This gives rise to thought that male patients show the symptoms of OSAS at an earlier age and these patients get early diagnosis. It is known that there is generally male predominance when the prevalence of OSAS is taken into consideration (13). The information which can give an explanation to these data observed in males is still not clear when both the prevalence and the average of age are considered. This difference can result from the fact that women pay less attention to the symptoms of OSAS (witnessed apnea, snoring, waking up with asphyxiation), they rarely see a doctor by taking these symptoms into consideration or the fact that doctors diagnose female patients with OSAS less frequently than male patients who consult doctors with the same complaints. It has been shown in the studies that another risk factor on female patients with OSAS can be menopause. It has been also shown that the prevalence of OSAS is higher among postmenopausal women when compared to premenopausal women and the majority of women with OSAS are in their postmenopausal period (14). In our study, menopause has not been examined in female patients and it has been seen that the average age of women is appropriate for the age of postmenopausal period.

Obesity is one of the major risk factor for OSAS and in our study it has been observed that women have higher average of BKI than men. The Wisconsin Sleep Cohort Study has shown that women have higher BKI than men in all OSAS ratings (15). Likewise it has been observed in our study that the number of women with morbid obesity is higher than the number of men and also $81.2 \%$ of patients who have the value of $\mathrm{BKI}>40$ are female and $18.8 \%$ of them are male. To the contrary with our study, Rajala and his friends have shown that the morbid obesity in male patients with OSAS is found to be at a higher percentage $(76.9 \%)$ (16). The different results obtained in the studies have given rise to the thought that the relation between morbid obesity and OSAS varies according to genetic and racial differences.

In our study, no differences have been determined between the two genders according to the results of ESS. Sleep Hearth Health Study has shown that there is a positive relationship between the score of ESS and $\mathrm{AHI}$ but there are no differences in the score between the genders (17). It has not been found a positive relation between $\mathrm{AHI}$ and ESS score in our study. The relation between ESS and genders has not been absolutely proved when the data in the literature are taken into consideration.

In our study, no significant differences between the two genders have been detected in terms of the three main symptoms of OSAS, which are snoring, excessive daytime sleepiness and witnessed apnea, and also the other symptoms such as the sweating of head and neck and headache. Supporting our study, Walker and his friends show in their study carried out among 575 men and 115 women that there are no significant differences between the two dangers in terms of the symptoms (18). In another study by Young and his friends, it has been determined that female patients with OSAS are more symptomatic than male patients even in the existence of mild OSAS and also the complaints of morning headache, anxiety and depression are seen in women at a higher percentage when compared to male patients (2). This gives rise to a thought that atypical symptoms such as insomnia, restless leg syndrome, depression, difficulty in falling asleep are seen more in female patients with OSAS. It has been shown in some studies that women with OSAS consult a doctor with atypical symptoms more than men $(17,18)$. The fact that women are missed out to be diagnosed with OSAS by clinicians can be explained by the fact that symptoms differs between the genders and clinicians ignore this diagnosis in women by considering OSAS as a male disease.

When the studies in the literature are viewed, it has been observed that OSAS is a risk factor for diseases such as HT, cardiovascular diseases, insulin resistance and diabetes mellitus. It has been determined in the studies that the risk of cardiovascular disease is higher in male patients with OSAS (19) while further problems such as depression and hypothyroidism are observed more frequently in female patients with OSAS $(20,21)$. The fact that no significant differences have been determined in terms of comorbidities in 
our study and different results from the literature have been reached gives rise to the thought that our study is retrospective and the deficiencies in data are effective.

In our study, no significant differences between female and male patients with OSAS have been determined in terms of the averages of TST (total sleep time), sleep onset and the average percentages of sleep efficiency. It has been observed that total sleep time does not differ between the two genders in most of the studies when the literature is analyzed (22). In a study in which 1000 patients have been evaluated, it has been shown that the rate of sleep efficiency is higher in men (23). Likewise in our study, no significant differences in sleep efficiency between women and men have been determined although lower average of sleep efficiency has been determined among women. The fact that women who have lower values of $\mathrm{AHI}$ than men have lower percentage of sleep efficiency indicates that women have the poor quality of sleep. The significantly lower rate of arousal index in female patients with OSAS than the male patients is one of the crucial findings of our study. Arousal index has been found to be lower in female patients with OSAS in one of the rare studies which evaluate arousal index like in our study (23). The detection of arousal index at a lower rate in women with OSAS can be explained by AHI averages found to be lower.

As it is expected to be, in OSAS N2 sleep time has increased in women and men with OSAS, REM sleep time has decreased but no significant differences in terms of N2 and REM sleep time have been determined between the two groups. The average N3 sleep time has been found to be significantly lower in male patients with OSAS while N1 sleep time has found to be significantly lower in female patients with OSAS.

It has been observed that the number and time of obstructive apnea in female patients with OSAS are significantly lower than male patients with OSAS. It has been found out that the number of hypopnea is the same as the number of obstructive apnea in female patients with OSAS and the number of hypopnea is lower than the number of obstructive apnea in male patients with OSAS. No significant differences between female and male patients with OSAS have been found in terms of the number and the time of hypopnea. No significant differences between the two genders have been obtained in terms of the num- ber and the time of central apnea. The number of mixed apnea has been found to be significantly higher in male patients with OSAS but no significant differences have been determined in terms of time. According to data obtained from the studies, partial obstruction in women with OSAS is seen higher than complete obstruction and respiratory cases last shorter (24). The dynamic features of upper respiratory are thought to play a role in the differences between the genders. Rowley and his friends have been able to reach some findings which support that women are less likely inclined to the collapse of respiratory ways than men and also that men have more pharyngeal collapsibility (25). It has been thought that hormones of women can have protective effects on dilator muscles of upper airways (26).

One of the most significant findings of our study is the fact that Total AHI has been found to be significantly higher in male patients with OSAS than female patients with OSAS. AHI NREM has been found to be higher in men with OSAS and AHI REM has been found to be higher in women with OSAS. However, unlike literature, no significant statistical differences have been found about the two parameters between the genders. According to the studies, it has been observed that OSAS progresses more mildly in women (27-29). O'Connor and his friends have shown that respiratory cases in women first pile in REM sleep period (29). There have not been any explanations yet for the reason why the number of REM apnea is higher in women. This case gives rise to the thought that functions of upper airways during sleep differ between women and men. Popovic and White have shown that genioglossaş muscle activation in more than in healthy female patients than males and they have anticipated that the case is a protective factor for women during their sleep (30). That the number of apnea during REM sleep is higher in women can be explained by the fact that the protective force preventing the collapse of airway during NREM sleep disappears during REM sleep. Cistulli and his friends have determined that the severity of OSAS does not change clinically with the hormone replacement treatment in postmenopausal women with OSAS but the number of apnea observed during REM sleep decreases (31). This gives rise to the thought that hormones are effective in the fact that more apnea is seen in women during REM sleep.

In our study, no significant differences between the two groups have been determined in terms of the 
average saturation values when night average and the lowest saturation averages are taken into consideration. However it has been observed that the lowest $\mathrm{SpO}_{2}$ average at night is significantly low in women with OSAS. In different studies, on the other hand, men with OSAS have been found to have more severe oxygen desaturations at night. The fact that there are different results related to the night average and the lowest saturation values gives rise to the thought that the studies about this subject are not sufficient and the difference of night saturation severity among women and men with OSAS is a subject which needs to be investigated.

When the divisions of female and male patients according to OSAS groups are taken into consideration, mild OSAS (AHI 5-15) has been observed in the majority of women (\%41.2) and severe OSAS has been observed in the majority of men $(\mathrm{AHI}>30)$. It has been proved in lots of studies that men have higher AHI values than women. This result supports the fact that female patients are more symptomatic than males although milder OSAS is seen in women when compared to men. It also supports that more severe OSAS exists in men although lower BKI is seen in male patients with OSAS.

As a result, we have observed in our study that women with OSAS are older and more obese than men with OSAS and they have lower AHI values and despite their lower AHI value, the symptoms of both genders are similar. Women are lucky about sleep but quantity and quality of sleep are worsely effected by internal (hormonal changes, vasomotor symptoms) and external factors (marriage problems, child caring) during their life. There are four different periods-menarche, pregnancy-lactationmenapause-deteriorating sleep quality in women but not in men. Unfortunately, women with sleep disorders are under-diagnosed due to circumstances related to the family life style and socio-cultural factors in addition to the different sleep disordered breathing clinical expression (32). We have also considered that these differences can result from genetic, racial, environmental, hormonal factors and the factors related to the functions of upper airways. For this reason, we want to emphasize that there is a need for extensive studies in which genetic and racial factor and hormonal conditions and the functions of upper airways are researched in order to the fact that the differences between women and men with OSAS more clearly.
Ethical Committee Approval: The approval for this study was obtained from Ankara Unıversity Faculty of Medicine Ethics Committee. (Decision No: 21-89614 Date: 22/12/2014).

\section{CONFLICT of INTEREST}

The authors of this study declare that they have no conflict of interest.

\section{AUTHORSHIP CONTRIBUTIONS}

Concept/Design: MEI, BG

Analysis/Interpretation: MEI, BG, FÇ

Data Acquisition: MEI, FÇ

Writting: MEI, BG

Critical Revision: MEI

Final Approval: All of authors

\section{REFERENCES}

1. Young T, Peppard PE, Gottlieb DJ. Epidemiology of obstructive sleep apnea: a population health perspective. Am J Resir Crit Care Med 2002; 165(9): 1217-39.

2. Young T, Hutton R, Finn L, Badr S, Palta M. The gender bias in sleep apnea diagnosis. Are women missed because they have different symptoms? Arch Intern Med 1996; 156(21): 2445-51

3. Young T, Peppard PE. Clinical presentation of OSAS: gender does matter. Sleep 2005; 28(3): 293-5.

4. Mohsenin V. Effects of gender on upper airway collapsibility and severity of obstructive sleep apnea. Sleep Med 2003; 4(6): 523-9.

5. Pillar G, Malhotra A, Fogel R, Beauregard J, Schnall R, White DP. Airway mechanics and ventilation in response to resistive loading during sleep: influence of gender. Am J Respir Crit Care Med 2000; 162(5): 1627-32.

6. Mohsenin V. Gender differences in the expression of sleepdisordered breathing: role of upper airway dimensions. Chest 2001; 120(5): 1442-7.

7. Millman RP, Carlisle CC, McGarvey ST, Eveloff SE, Levinson $P D$. Body fat distribution and sleep apnea severity in women. Chest 1995; 107(2): 362-6.

8. Whittle AT, Marshall I, Mortimore IL, Wraith PK, Sellar RJ, Douglas NJ. Neck soft tissue and fat distribution: comparison between normal men and women by magnetic resonance imaging. Thorax 1999; 54(4): 323-8.

9. Zhou XS, Shahabuddin S, Zahn BR, Babcock MA, Badr MS. Effect of gender on the development of hypocapnic apnea/hypopnea during NREM sleep. I Appl Physiol 2000; 89(1): 192-9.

10. Popovic RM, White DP. Upper airway muscle activity in normal women: influence of hormonal status. I Appl Physiol 1998; 84(3): 1055-62. 
11. Dancey DR, Hanly PJ, Soong C, Lee B, Shepard J/, Hoffstein V. Gender differences in sleep apnea: the role of neck circumference. Chest 2003; 123(5): 1544-50.

12. Leech JA, Onal E, Dulberg C, Lopata MA. A comparison of men and women with occlusive sleep apnea syndrome. Chest 1988; 94(5): 983-8.

13. Ye L, Pien GW, Weaver TE. Gender differences in the clinical manifestation of obstructive sleep apnea. Sleep Med 2009; 10(10): 1075-84.

14. Rajala R, Partinen M, Sane T, Pelkonen R, Huikuri K, Seppäläinen AM. Obstructive sleep apnea in morbidly obese patients. J Intern Med 1991; 230: 125-9.

15. Gottlieb DJ, Whitney CW, Bonekat WH, Iber C, James GD, Lebowitz $M$, et al. Relation of sleepiness to respiratory disturbance index: the Sleep Heart Health Study. Am J Respir Crit Care Med 1999; 159(2): 502-7.

16. Walker RP, Durazo-Arvizu R, Wachter B, Gopalsami C. Preoperative differences between male and female patients with sleep apnea. Laryngoscope 2001; 111(9): 1501-5.

17. Wahner-Roedler DL, Olson EJ, Narayanan S, Sood R, Hanson AC, Loehrer $L L$, et al. Gender-specific differences in a patient population with obstructive sleep apneahypopnea syndrome. Gend Med 2007; 4(4): 329-38.

18. Valipour $A$, Lothaller $H$, Rauscher $H$, Zwick $H$, Burghuber OC, Lavie P. Genderrelated differences in symptoms of patients with suspected breathing disorders in sleep: a clinical population study using the sleep disorders questionnaire. Sleep 2007; 30(3): 312-9.

19. Vagiakis E, Kapsimalis $F$, Lagogianni I, Perraki $H$, Minaritzoglou A, Alexandropoulou K, et al. Gender differences on polysomnographic findings in Greek subjects with obstructive sleep apnea syndrome. Sleep Med 2006; 7: 424-30.

20. Shepertycky MR, Banno K, Kryger MH. Differences between men and women in the clinical presentation of patients diagnosed with obstructive sleep apnea syndrome. Sleep 2005; 28(3): 309-14.

21. Halvorson DJ, Porubsky ES. Obstructive sleep apnea in women. Otolaryngol Head Neck Surg 1998; 119(5): 497501.
22. Smith R, Ronald J, Delaive K, Walld R, Manfreda J, Kryger $\mathrm{MH}$. What are obstructive sleep apnea patients being treated for prior to this diagnosis? Chest 2002; 121(1): 164-72.

23. Alotair H, BaHammam A. Gender differences in Saudi patients with obstructive sleep apnea. Sleep Breath 2008; 12: 323-9.

24. Leech J, Onal E, Dulberg C, Lopata M. A comparison of men and women with occlusive sleep apnea syndrome. Chest 1998; 94(5): 983-7.

25. Rowley IA, Zhou X, Vergine I, Shkoukani MA, Badr MS. Influence of gender on upper airway mechanics: upper airway resistance and Pcrit. I Appl Physiol 2001; 91(5): 2248-54.

26. Popovic RM, White DP. Upper airway muscle activity in normal women: influence of hormonal status. I Appl Physiol 1998; 84(3): 1055-62.

27. Millman RP, Carlisle CC, McGarvey ST, Eveloff SE, Levinson $P D$. Body fat distribution and sleep apnea severity in women. Chest 1995; 107(2): 362-6.

28. Ware JC, McBrayer RH, Scott JA. Influence of sex and age on duration and frequency of sleep apnea events. Sleep 2000; 23(2): 165-70.

29. O'Connor C, Thornley KS, Hanly P. Gender influence in the polysomnographic features of obstructive sleep apnea. Am J Respir Crit Care Med 2000; 161(5): 1465-72.

30. Popovic RM, White DP. Influence of gender on waking genioglossus electromyogram and upper airway resistance. Am J Respir Crit Care Med 1995; 152: 725-31.

31. Cistulli PA, Barnes DJ, Grunstein RR, Sullivan CE. Effect of short term hormone replacement in the treatment of obstructive sleep apnea in postmenopausal women. Thorax 1994; 46: 699-702.

32. Dursunoğlu N. Woman and man distinctions during sleepdo we differ also in sleeping? Turkiye Klinikleri J Cardiol-Special Topics 2018; 11(1): 29-31 